\title{
10. CALCAREOUS NANNOFOSSIL BIOSTRATIGRAPHY FROM THE JAPAN SEA, SITES 798 AND 799: EVIDENCE FOR AN OSCILLATING PLEISTOCENE OCEANOGRAPHIC FRONTAL BOUNDARY ${ }^{1}$
}

\author{
Jay Phillip Muza ${ }^{2}$
}

\begin{abstract}
Preliminary results of the biostratigraphic analysis of calcareous nannofossils recovered from Ocean Drilling Program Leg 128, Sites 798 and 799, provide clues to the Quaternary oceanography of the Japan Sea. The distribution of calcareous nannofossils from the Quaternary sediments at Site 798 ( $903 \mathrm{~m}$ water depth) may record the position of an oceanographic frontal boundary between warm water derived from a branch of the Kuroshio Current as it entered the Japan Sea through the Tsushima Straits to the south, and colder water introduced into the western portion of the Japan Sea derived from the winter chilling of northern Japan Sea surface waters. This oceanographic front probably oscillated north-south over Site 798 in response to glacial/interglacial cycles, or perhaps to some other climatic event or combination of events unique to the Japan Sea. During the last 1.5 m.y., six major intervals are recognized when the oceanographic front may have been north of Site 798 separated by five major intervals when the frontal boundary may have been south of the site. These migrations were centered around approximately $0.125,0.29$, $0.56,0.62,0.85,0.91,0.98,1.0,1.11$, and $1.5 \mathrm{Ma}$, which correspond to the boundaries separating nannofossil-rich sediments from barren or nearly barren, low-carbonate intervals. Nannofossil-rich intervals may represent times when the frontal boundary was north of Site 798, and the site was above the CCD. Barren or nearly barren intervals represent times when the frontal boundary may have been south of Site 798 and the CCD was probably higher. The distribution of calcareous nannofossils at Site 799 ( $2073 \mathrm{~m}$ water depth) appears to be controlled more by the depth of the CCD than by any climatic effects.

The FOD (first occurrence datum) of Emiliania huxleyi, the LOD (last occurrence datum) of Psuedoemiliania lacunosa, Helicosphaera sellii, Calcidiscus macintyrei $(10 \mu \mathrm{m})$, and the FOD and LOD of Reticulofenestra asanoi are recognized from Site 798 cores. The LOD of $P$. lacunosa is observed in sediments from Site 799.

Only in the sediments younger than $1.5 \mathrm{Ma}$ are the nannofossils from Sites 798 and 799 preserved well enough and sufficiently numerous for age dating and paleoceanographic conjecture. $I n$-situ dissolution in older sediments at both sites precludes any dating or paleoenvironmental interpretations.
\end{abstract}

\section{INTRODUCTION}

During Ocean Drilling Program Leg 128, three holes were drilled at Site 798 (water depth $=903 \mathrm{~m}$ ) and two holes at Site 799 (water depth $=2073 \mathrm{~m}$ ) in the Japan Sea (Fig. 1). Quaternary, Pliocene, and Miocene sediments were recovered at these sites from sediment-filled grabens that were created during various back-arc rifting events during the Miocene and possibly the late Oligocene (Fig. 2).

The primary objective at Site 798 was to obtain a Miocene to Holocene paleoceanographic reference section in sediment deposited above the carbonate compensation depth (CCD). Previous studies have shown that the Japan Sea has had a shallow CCD $(1500-2000 \mathrm{~m})$ throughout much of its Neogene history (Ingle, 1975). Thus, carbonate-rich sections suitable for climatic and paleoceanographic studies are available only at shallow water sites away from the influence of gravity flow sediments.

The primary objective at Site 799 was to detail the depositional and tectonic history of a failed rift regime. Although the water depth at this site is below the present day CCD, carbonate-rich intervals within the sediments from the Miocene through Quaternary at Site 799 may indicate a history of CCD fluctuations.

Age dating of the Leg 128 sediments is important to further understand the formation and evolution of the Japan Sea and to provide a paleoceanographic history of a back-arc basin as it responds to tectonic growth. Signals of climate, sea-level fluctuations, and glacial-interglacial cycles recorded in the sediments of the Japan Sea most certainly have imprinted upon them other signals that are unique

\footnotetext{
${ }^{1}$ Pisciotto, K. A., Ingle, J. C., Jr., von Breymann, M. T., Barron, J., et al., 1992. Proc. ODP, Sci. Results, 127/128, Pt. 1: College Station, TX (Ocean Drilling Program).

2 Jay Phillip Muza, Department of Oceanography, Florida State University, Tallahassee, FL 32306 , U.S.A.
}

to a developing back-arc basin with no deep-water connection to the Pacific Ocean. In this chapter, I discuss the results of the preliminary analysis of calcareous nannofossils from cores recovered from Sites 798 and 799. Calcareous nannofossils from the Japan Sea have also been studied by Ellis (1975) from Deep Sea Drilling Project Leg 31 cores and by Rahman (this volume) from Ocean Drilling Program Leg 127 cores.

\section{Site 798}

Site 798 is located at $37^{\circ} 38^{\prime} \mathrm{N}, 134^{\circ} 80^{\prime} \mathrm{E}$ on the Oki Ridge in a small sediment-filled graben at a water depth of $903 \mathrm{~m}$ in the southeast quadrant of the Japan Sea $\sim 160 \mathrm{~km}$ north of the western coast of Honshu (Fig. 1). The Oki Ridge is typical of the numerous ridges and banks that are bounded by steep normal faults that parallel Honshu and Hokkaido in the eastern and southern portion of the Japan Sea and the western side of the Yamato Basin (Tamaki, 1988). Miocene through Quaternary sediments record the formation and uplift of the modern Oki Ridge. Benthic foraminifer evidence suggests that the Oki Ridge benthic environment has been characteristic of upper middle bathyal conditions ( $1000 \mathrm{~m}$ water depth) for the last $1.5 \mathrm{~m}$.y. (Kato, this volume). Kato further suggests that the ridge has been uplifted $\sim 1000 \mathrm{~m}$ during the last $4 \mathrm{~m}$.y.

Hole $798 \mathrm{~A}$ was cored with the advanced hydraulic piston core (HPC) system to a depth of $142.5 \mathrm{~m}$ below seafloor (mbsf) and cored by extended core barrel (XCB) to $143.3 \mathrm{mbsf}$ before termination in a dolomite-cemented siliceous ooze. Seventeen cores were recovered from Hole $798 \mathrm{~A}$ with a total core recovery of $103 \%$ due to sediment expansion resulting from the depressurization of natural gases in the core liner on deck. Hole 798B was cored $\sim 20$ m north of Hole 798A. Continuous HPC cores were taken to 142.6 mbsf with a total core recovery of $>100 \%$, again due to expansion of natural gases within the sediments. Continuous XCB cores were taken from $142.6 \mathrm{mbsf}$ to a depth of $517.9 \mathrm{mbsf}$, where the coring was terminated due to 


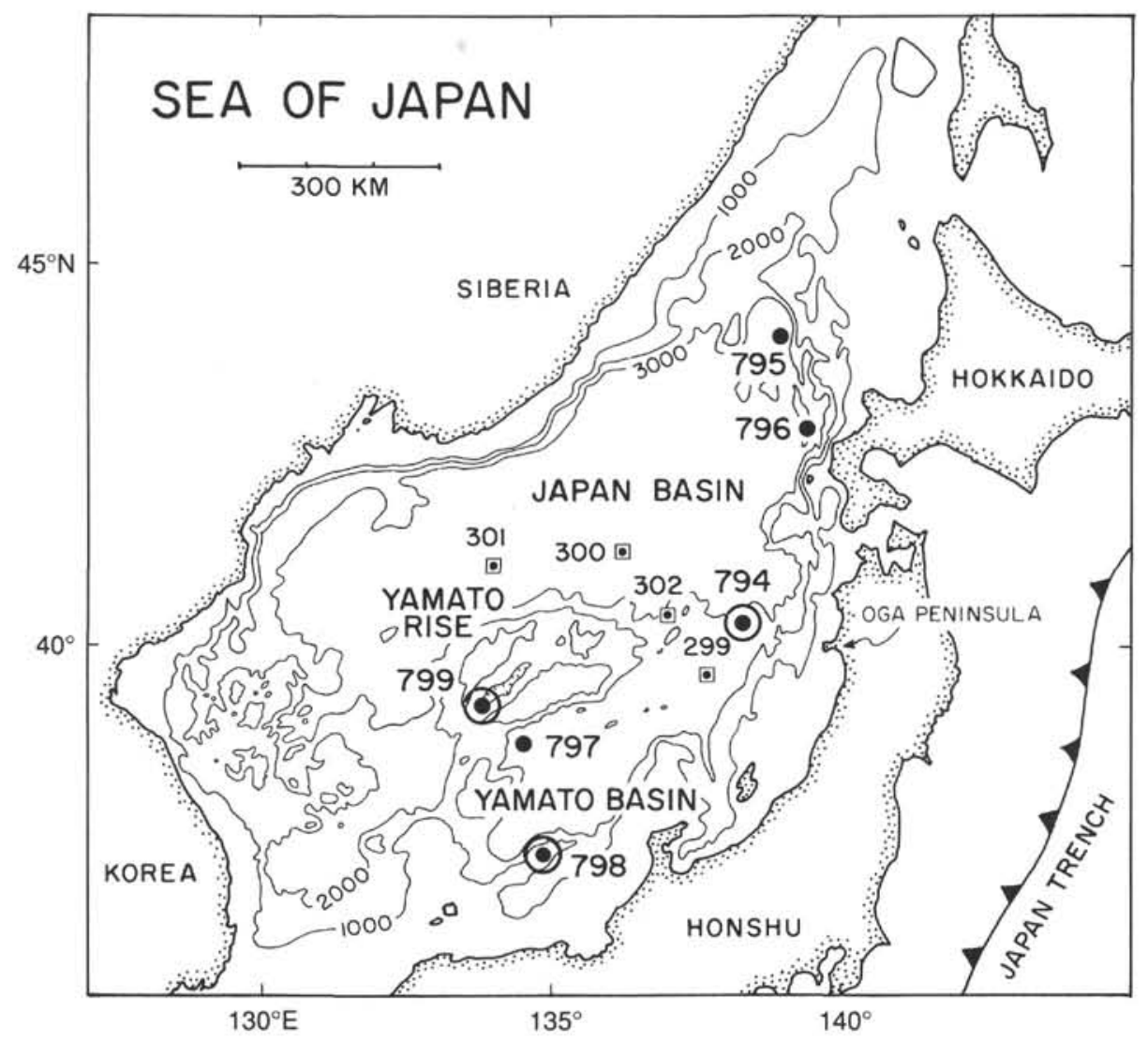

Figure 1. Location of Ocean Drilling Program Leg 128 Sites (circled dots), Leg 127 sites (dots), and Deep Sea Drilling Project Leg 31 sites (squares). Bathymetry is in meters.

anomalously high natural gas concentrations. A total of 54 cores was recovered from Hole $798 \mathrm{~B}$ with a recovery of $99.3 \%$. Hole $798 \mathrm{C}$ was spudded after the JOIDES Resolution was offset $20 \mathrm{~m}$ north. Continuous HPC cores were taken to 120.1 mbsf with a recovery of $110 \%$. Shipboard sampling was not done for Hole $798 \mathrm{C}$ because of redundant sediment recovery.

The sediments recovered from Site 798 were divided into three sedimentary units by the shipboard sedimentologists (Ingle, Suyehiro, von Breymann, et al., 1990). Unit I, (late Quaternary-late Pliocene; 0-220 mbsf) is composed of clay, silty clay, diatomaceous clay, and diatom ooze, interbedded with foraminifer and calcareous nannofossil bearing intervals. Compared to the units downsection, nannofossils are most abundant in this unit. This interval is characterized by centimeter to several meters thick beds of dark gray, laminated sediments alternating with lighter colored gray or greengray homogeneous or bioturbated sediments. Calcareous nannofossils tend to be most abundant in the 10-50-cm-thick lighter colored bioturbated intervals between 30 and $160 \mathrm{mbsf}$. In contrast, the darker laminated sediments are more enriched in diatoms, foraminifers, and organic carbon. Approximately 100 ash layers ( $1 \mathrm{~mm}-15 \mathrm{~cm}$ thick) occur within this unit.

Unit II (late Pliocene; $220-455$ mbsf) is composed of diatomaceous clay interbedded with diatom ooze and silty clay. There is a noticeable absence of the well-laminated/bioturbated sequence and the calcareous nannofossil-rich layers that characterize Unit I. Extensive bioturbation is common. Diatom abundances decrease abruptly below 373 mbsf with only the most solution-resistant forms common.

Unit III (late early Pliocene; 455-518 mbsf) is comprised of siliceous claystone and claystone. The upper boundary approximates the opal-A-opal-CT transition zone. Dark, laminated sediments alter- nate with lighter colored, bioturbated intervals similar to those in Unit I throughout most of the section. Carbonates are virtually absent.

\section{Site 799}

Site 799 is located at $39^{\circ} 22^{\prime} \mathrm{N}, 133^{\circ} 86.6^{\prime} \mathrm{E}$ on the Yamato Rise within the Kita-Yamato Trough, which is a sediment-filled graben in the south-central Japan Sea (Fig. 1). The Yamato Rise is the largest bathymetric high in the Japan Sea that is not contiguous to the Japanese mainland. The Kita-Yamato Trough is composed of three discrete, nested, parallel grabens that trend northeast-southwest along the long axis of the Yamato Rise for a distance of $\sim 130 \mathrm{~km}$ (measured along the $2000-\mathrm{m}$ isobath). Throughout the Japan Sea, northeast- or northward-trending normal faults are the common tectonic components of the numerous banks, troughs, and grabens that parallel the Japanese Islands. This widespread extensional faulting occurred at the onset of back-arc rifting during the early Miocene and possibly the late Oligocene (Iijima and Tada, 1990). The Yamato Rise is most probably a continental fragment isolated by multiple rifting events during this time, and the Kita-Yamato Trough represents a failed rift that began to collect sediments at the time of failure.

Hole 799A was drilled in $2073 \mathrm{~m}$ of water to a depth of $468.7 \mathrm{mbsf}$. Four-hundred forty meters of sediment was recovered in 54 cores for a core recovery of $93 \%$. Core recovery exceeded $100 \%$ in the upper 24 cores; nannofossils are most abundant in this interval. Below this interval, nannofossils are found at only two horizons.

Hole 799B was spudded after the JOIDES Resolution moved $20 \mathrm{~m}$ north. Hole 799B was drilled to $450 \mathrm{mbsf}$ to overlap the cored sediment section in Hole 799A, and then rotary cored to $1084 \mathrm{mbsf}$ where drilling was terminated. No sediment was recovered in Core 128-799B-1R. Only 


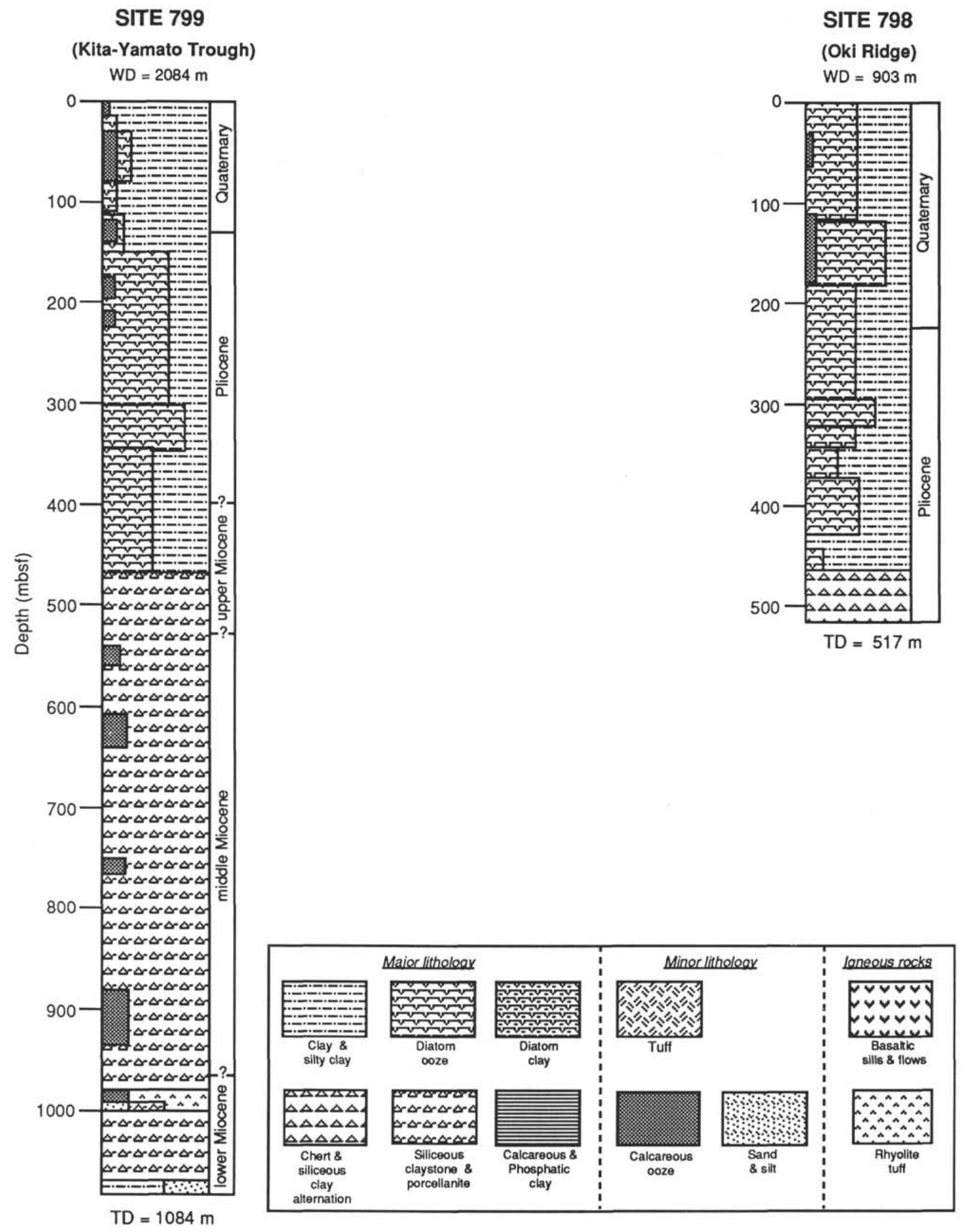

Figure 2. Sites 798 and 799 composite lithologic columns. 


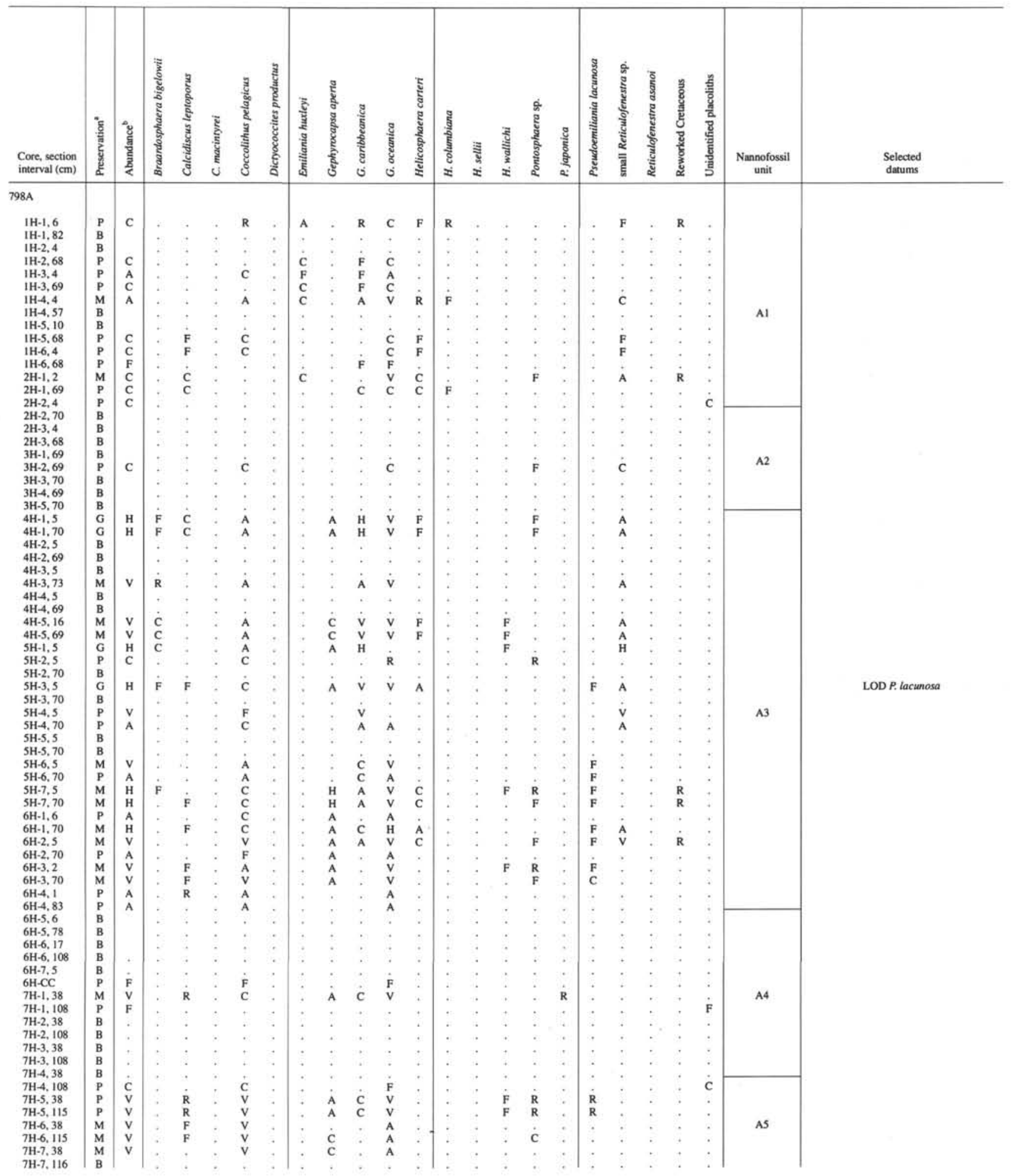

$0.22 \mathrm{~m}$ of sediment was recovered in Core $128-799 \mathrm{~B}-2 \mathrm{R}$ and no sediment was recovered in Cores $128-799 B-3 R$ and $-4 R$. The first substantial amount of sediment was recovered in Core 128-799B-5R. Sixty-seven cores, representing $633 \mathrm{~m}$ of section, recovered $280.5 \mathrm{~m}$ of sediment for a total core recovery of $44 \%$.

The sediments from Site 799 (Fig. 2) were divide into five distinct lithologic units by the shipboard sedimentologists (Ingle, Suyehiro, von Breymann, et al., 1990). Unit I (Quaternary to late Pliocene; $0-170$ mbsf) is composed principally of diatomaceous ooze, diatomaceous clay, and varying mixtures of clays and silts. Compared to Unit I at Site 798, this unit does not have as many layers containing foraminifers and calcareous nannofossils. The carbonate microfossils become progressively dissolved and overgrown with depth so that below 100 mbsf identification is difficult or impossible. The upper 
Table 1 (continued).

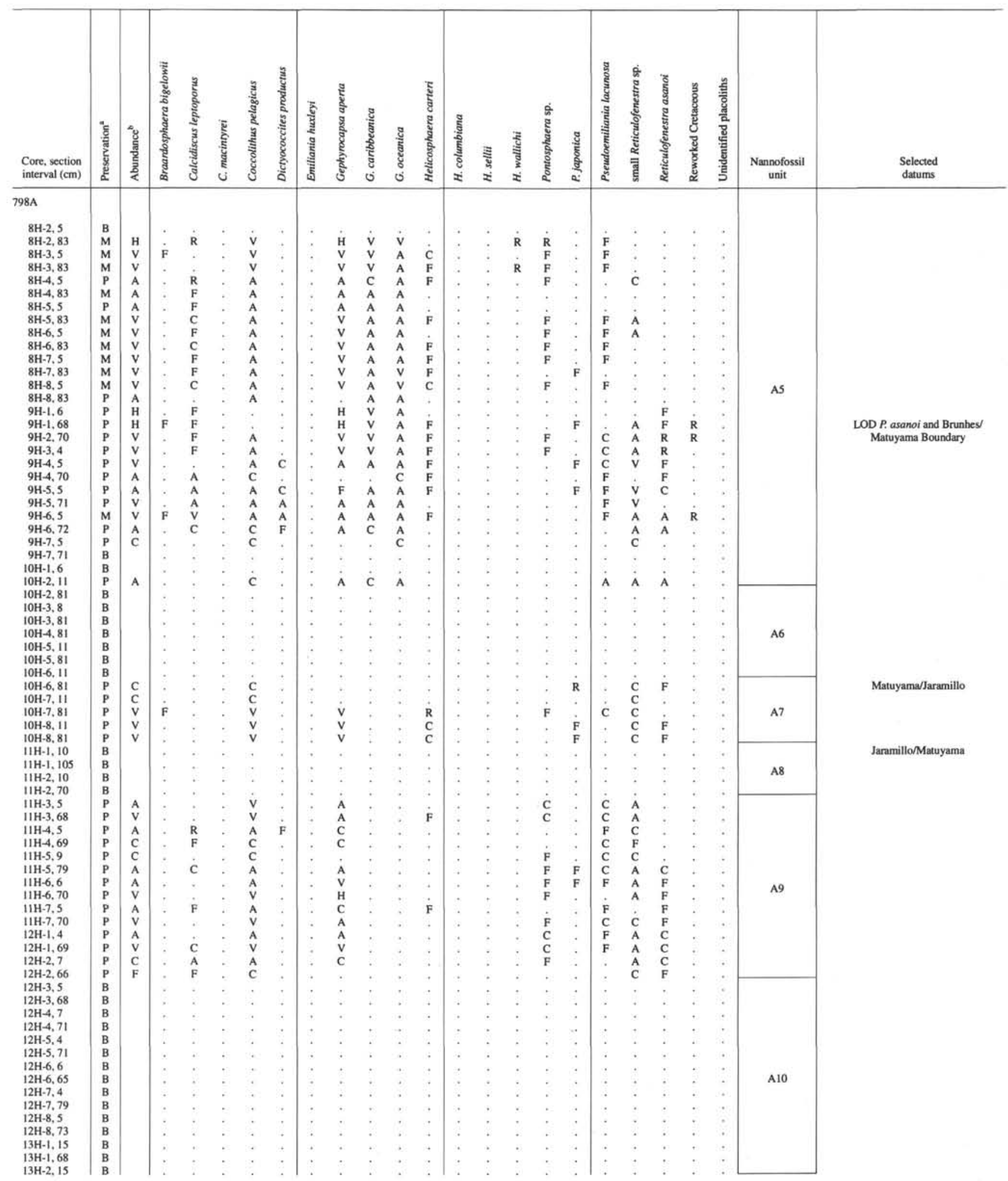


Table 1 (continued).

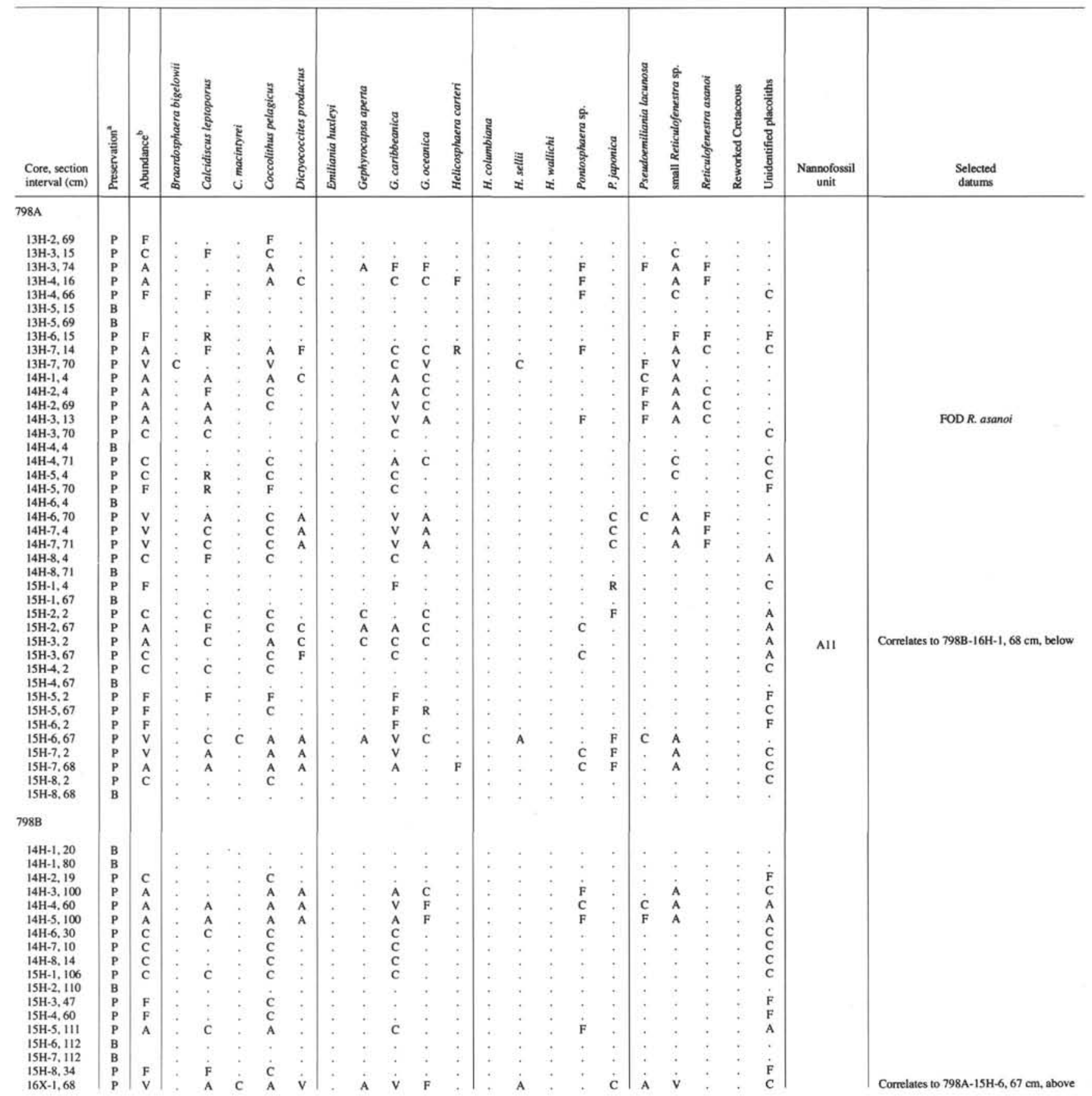

part of this unit is laminated and bedded with alternating light and dark layers.

Unit II (late Pliocene to late Miocene; $170-457$ mbsf) is predominantly a diatomaceous ooze with varying amounts of clay. Dolomite beds and calcite beds occurring as chalky layers between 247 and $394 \mathrm{~m}$ may represent diagenetically altered foraminiferal and nannofossil-rich layers. Many of the grains that make up these beds are $<10 \mu \mathrm{m}$ in diameter (nannofossil size).

Unit III (late to middle Miocene; $457-800 \mathrm{mbsf}$ ) is composed mainly of siliceous claystone and porcellanite with concretions of authigenic carbonates. Nannofossils are absent within this unit.

Unit IV (middle Miocene; $800-1020 \mathrm{mbsf}$ ) is composed of siliciclastic distal turbidite deposits, siliceous claystone, and porcellanite,

all with interlaminated authigenic carbonates. Calcareous nannofossils are present at 974 mbsf.

Unit V (early Miocene?; 1020-1084 mbsf) is composed of claystone and siliceous claystone interbedded with coarse-grained siliciclastic turbidites $\leq 5 \mathrm{~m}$ thick. Displaced shallow-water benthic foraminifers, calcareous shell debris, and terrestrial plant debris are common in the sand layers.

\section{METHODS}

Calcareous nannofossil assemblages are described from smear slides made from samples taken at intervals of two/section from Holes 798A, 798B, 799A, and 799B. The distribution, abundance, and 
Table 1 (continued).

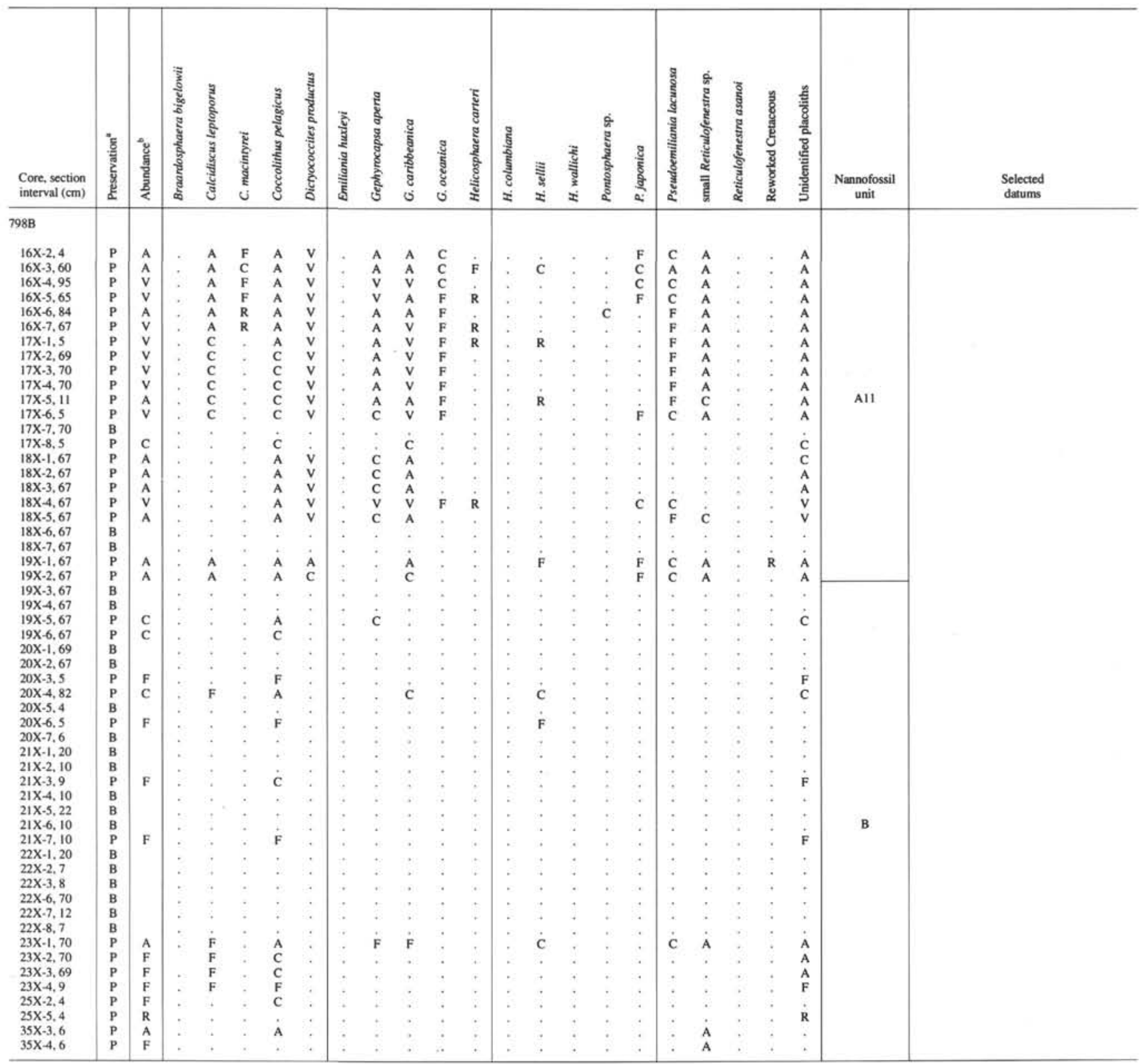

Note: Barren samples are labeled B. Holes 798A and 798B may be correlated. Samples 128-798A-15H-6, $67 \mathrm{~cm}$, and 128-798B-16X-1, $68 \mathrm{~cm}$, represent the same horizon.

"Abundance: $\mathrm{H}=$ highly abundant; $\mathrm{V}=$ very abundant; $\mathrm{A}=$ abundant; $\mathrm{C}=$ common; $\mathrm{F}=$ few; $\mathrm{R}=$ rare.

Preservation: $\mathrm{G}=$ good: $\mathrm{M}=$ moderate: $\mathrm{P}=$ poor.

preservation of all species are plotted on Tables 1 and 2. Smear slides were made directly from the unprocessed sediment sample and examined at magnifications of $1560 \times$ and $1000 \times$ on a Zeiss light microscope using phase contrast and crossed-polarized light. Estimates of the abundances of individual nannofossil species on the smear slides were tabulated on range charts using the method of Hay (1970). Letters used to denote abundances reflect the $\log _{10}$ of the number of specimens of a taxon likely to be observed in any one field of view at $1000 \times$. These letters are determined as follows:

$\mathrm{H}=$ Highly abundant ( $>100$ specimens/field of view)

$\mathrm{V}=$ Very abundant (11-100 specimens/field of view)

$A=$ Abundant $(1-10$ specimens/field of view)

\section{$\mathrm{C}=$ Common $(1$ specimen $/ 2-10$ fields of view $)$ \\ $\mathrm{F}=\mathrm{Few}(1$ specimen $/ 11-100$ fields of view) \\ $\mathrm{R}=\mathrm{Rare}(1$ specimen/101-1000 fields of view)}

Approximately $300-400$ fields of view were observed/smear slide.

Through visual inspection at $1560 \times$, a qualitative determination was made of the state of preservation of the nannofossils in each sample. In any given sample, the state of preservation may differ between each individual species, genus, or morphologic group. Thus, any qualitative measurement of a given sample must be based on the overall preservation qualities of the nannofossil assemblage. The following basic criteria were used to qualitatively describe the degree of preservation, dissolution, or overgrowth of a nannofossil assemblage: 
Table 2. Distribution of Site 799 calcareous nannofossils.

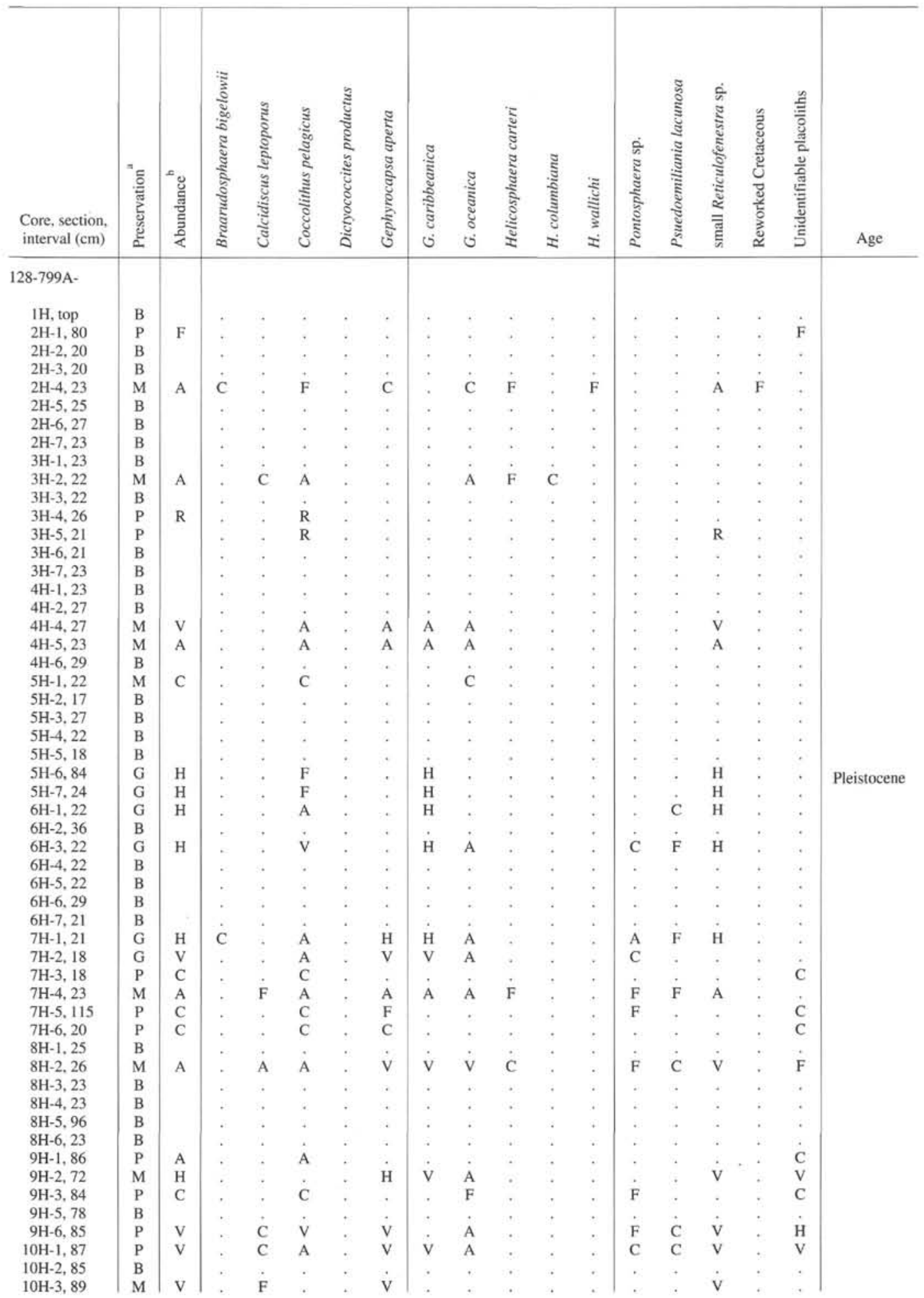

$\mathrm{G}=\mathrm{Good}$ (individual specimens exhibit no dissolution or overgrowth).

$\mathrm{M}=$ Moderate (individual specimens yield slight evidence of overgrowth or dissolution; central bars of gephyrocapsids present; elements of calcidiscids prominent).

$\mathrm{P}=$ Poor (individual specimens exhibit considerable dissolution and overgrowth; placoliths are ragged; gephyrocapsids commonly have their central bars dissolved; elements are not prominent in calcidiscids; species identification is difficult and often impossible).
More than $90 \%$ of the Site 798 and 799 nannofossil assemblages exhibit poor preservation. All assemblages exhibit at least moderate dissolution of most species.

\section{Stratigraphic Standards}

Stratigraphic resolution and age determination is accomplished by using the following globally synchronous calcareous nannofossil 
Table 2 (continued).

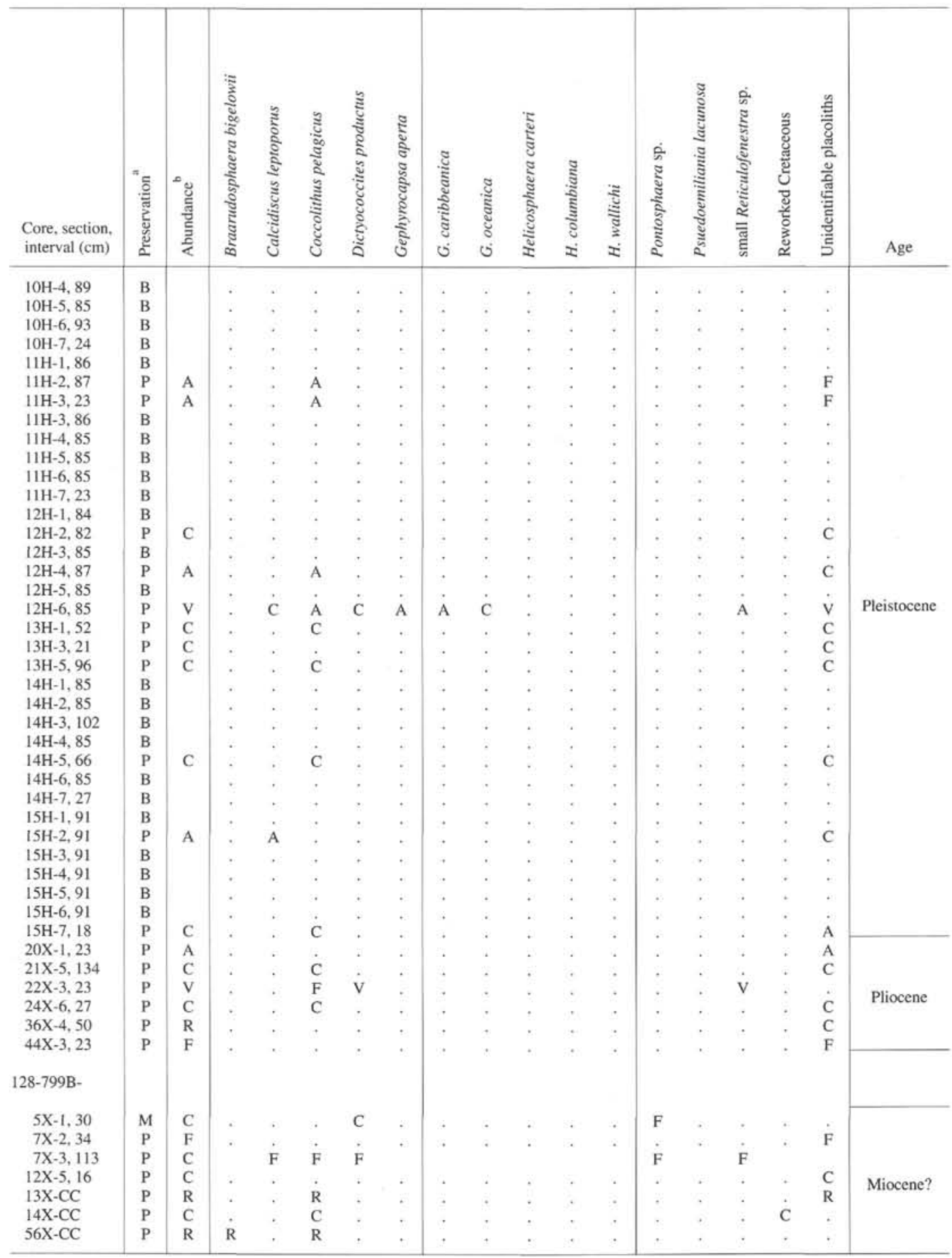

Note: Barren samples are labeled B.

Abundance: $\mathrm{H}=$ highly abundant; $\mathrm{V}=$ very abundant; $\mathrm{A}=$ abundant; $\mathrm{C}=$ common; $\mathrm{F}=$ few; $\mathrm{R}=$ rare.

${ }^{b}$ Preservation: $\mathrm{G}=$ good; $\mathrm{M}=$ moderate $\mathrm{P}=$ poor.

extinction (last occurrence datum; LOD) event and paleomagnetic datums. The surface sediments are assumed to be recent.

LOD Pseudoemiliania lacunosa $=0.458 \mathrm{Ma}$ (Thierstein et al., 1977) Brunhes/Matuyama Chron boundary $=0.73 \mathrm{Ma}$ (Berggren et al., 1985)

Matuyama/Jaramillo boundary $=0.91 \mathrm{Ma}$ (Berggren et al., 1985)

Jaramillo/Matuyama boundary $=0.98 \mathrm{Ma}$ (Berggren et al., 1985)

Matuyama/Olduvai boundary $=1.66 \mathrm{Ma}$ (Berggren et al., 1985)
Age determination of sample horizons for this report is accomplished by interpolating between the biostratigraphic or paleomagnetic datums closest to the sample horizon. Errors in the calculated age due to the sampling interval are listed:

Recent-LOD P. lacunosa $= \pm 8.6$ k.y.

LOD $P$. lacunosa-Brunhes/Matuyama $= \pm 11.4$ k.y.

Brunhes/Matuyama-Matuyama/Jaramillo $= \pm 17.8 \mathrm{k} . \mathrm{y}$. 
Matuyama/Jaramillo-Jaramillo/Matuyama $= \pm 25.7 \mathrm{k} . \mathrm{y}$.

Jaramillo/Matuyama-Matuyama/Olduvai $= \pm 13.1$ k.y.

The LOD of Helicosphaera sellii is also utilized in this report although Backman and Shackleton (1983) cautioned that this LOD is diachronous; $H$. sellii disappears from the middle latitudes before its extinction at $1.37 \mathrm{Ma}$ in the equatorial Pacific. In other parts of the world, reported LOD's for $H$. sellii are 1.22 Ma in the North Atlantic (Pujos, 1985a), 1.10-1.27 Ma at six DSDP Leg 94 drill sites in the North Atlantic (Takayama and Sato, 1986), 1.22 Ma in the equatorial Pacific (Gartner, 1977), 1.23 Ma in the central equatorial Pacific (Pujos, 1985a), and 1.20 Ma in the subtropical northwestern Pacific Ocean (Matsuoka and Okada, 1989). Backman and Shackleton (1983) questioned whether the $1.37 \mathrm{Ma}$ disappearance of $\mathrm{H}$. sellii might be due to selective dissolution and concluded that dissolution did not effect this datum. It appears, however, that the LOD of $H$. sellii at other sites in the Atlantic and Pacific oceans supports an $\sim 1.2 \mathrm{Ma}$ extinction date.

The various species assigned to the genus Gephyrocapsa Kamptner (1943) were not used in this study for biostratigraphic age control because there is no consensus among nannofossil researchers regarding species concepts. This is partly due to the criteria (i.e., angle of bridge, shield roundness, size of central opening, rim width, and number of shield elements) some workers have used to split this genus at the species level using electron microscopy (Sambtleben, 1980; Pujos-Lamy, 1977; Pujos, 1985b; Matsuoka and Okada, 1989 and 1990; and others). Compounding this problem is the small size of the gephyrocapsids, which makes identification difficult at the species level in light microscope studies.

The lack of consistency in species concept has led to considerable confusion in determining the FOD's of $G$. oceanica and $G$. caribbeanica which are used in some biostratigraphic zonal schemes. For example, the FOD of $G$. oceanica has been reported by Bukry (1973) at $0.9 \mathrm{Ma}$, by Haq et al. (1977) at $1.57 \mathrm{Ma}$, by Gartner (1977) at 1.51 and $1.65 \mathrm{Ma}$, and by Takayama and Sato (1986) at $1.57 \mathrm{Ma}$. Both Bukry's (1973) and Gartner's (1977) nannofossil zonation schemes are partly dependent on gephyrocapsids for their zonations in the Quaternary. Primarily for this reason, but also because of sporadic nannofossil distribution and poor preservation in the lower Pleistocene sediments, I have chosen not to use any of the established nannofossil biostratigraphic zonal schemes in this report. Recent discussions on the taxonomic problems associated with the gephyrocapsids are provided by Sambtleben (1980), Perch-Nielsen (1985), Rahman and Roth (1989), and Matsuoka and Okada (1990). Certainly, the "Gephyrocapsa problem" must be remediated, but this is beyond the purpose of this report.

In this report I recognize three species of Gephyrocapsa that can be identified under the light microscope at $1560 \times$ magnification. Gephyrocapsa oceanica Kamptner (1943, p. 43-49) is $3 \mu \mathrm{m}$ or larger along the long axis with a bridge angle oriented from $0^{\circ}$ to $45^{\circ}$ to the shorter axis. Gephyrocapsa caribbeanica Boudreax and Hay (in Hay et al., 1967, p. 447 , pl. $12-13$, figs. $1-4$ ) is $3 \mu \mathrm{m}$ or larger along the long axis with a bridge oriented at an angle $>45^{\circ}$ to the short axis. Gephyrocapsa aperta Kamptner, 1963 (p. 173 , pl. 6, figs. 32-35) is smaller than G. caribbeanica with a bar oriented $45^{\circ}$ or more to the short axis. A species that might be included in this description is $G$. sinuosa.

Taxa considered in this chapter are listed in the appendix and arranged alphabetically by genus. Bibliographic references for these epithets are found in Perch-Nielson (1985).

\section{HOLE SUMMARIES}

\section{Site 798}

Calcareous nannofossils are described from Holes 798A and 798B. Cores $128-798 \mathrm{~A}-1 \mathrm{H}$ through $-15 \mathrm{H}$ are described from Hole $798 \mathrm{~A}$. Cores $128-798 \mathrm{~B}-14 \mathrm{H}$ through $-54 \mathrm{X}$ are described from Hole $798 \mathrm{~B}$.
These holes maybe correlated based on the occurrence of abundant $H$. sellii and the last appearance of $C$. macintyrei in Samples 128798A-15H-6, $67 \mathrm{~cm},(140.87 \mathrm{mbsf})$ and 128-798B-16H-1, $68 \mathrm{~cm}$ (143.26 mbsf) (Table 1). Therefore, this horizon at Site 798B is $\sim 2.4$ mbsf deeper than it is at Site 798A.

Hole 798A was spudded into upper Pleistocene sediment in $903 \mathrm{~m}$ of water on the Oki Ridge. Throughout most of the Pleistocene sediments, calcareous nannofossils occur in well-defined intervals separated by equally well-defined barren intervals. From the lower Pleistocene sediments down to the bottom of the section, nannofossils occur only sporadically in very sparse, low-diversity assemblages. Generally, nannofossil preservation is poor to extremely poor and assemblage abundances range from few to highly abundant. The sample resolution ranges from $\sim 8,500$ to $13,000 \mathrm{yr}$ between samples. No hiatuses were recognized in Hole 798A.

\section{Datums}

Five nannofossil datums and four paleomagnetic datums are recognized in the Site 798 sediments.

The FOD? of E. huxleyi is found at 9.3 mbsf at Site 798, which corresponds to an age of $0.268 \mathrm{Ma}$. This first appearance of $E$. huxleyi at this site is considered to be an unreliable FOD because of severe dissolution and sporadic occurrence. Likewise, the reversal in dominance level between $G$. caribbeanica and $E$. huxleyi in the latter one third of the range of $E$. huxleyi is obscured by dissolution and sporadic occurrence.

The LOD of $P$. lacunosa is located at $39.75 \mathrm{mbsf}$ and represents an age of $0.458 \mathrm{Ma}$.

The LOD and FOD of Reticulofenestra asanoi are recognized in Hole 798A at 75 and 131.72 mbsf respectively. The LOD of $R$. asanoi in this hole is very close to the Brunhes/Matuyama boundary (75.34 mbsf; $0.73 \mathrm{Ma}$ ) and may be considered concurrent with this event at Site 798. Interpolation between the base of the Jaramillo $(94.65 \mathrm{~m}$; $0.98 \mathrm{Ma}$ ) and the top of the Olduvai (200.8 mbsf; $1.66 \mathrm{Ma}$ ) provides an age of $\sim 1.17 \mathrm{Ma}$ for the FOD of $R$. asanoi at this site. These datums are considered reliable because $R$. asanoi is relatively abundant where it is recognized, reworking is not apparent, and the datums occur in the middle of long stratigraphic intervals of abundant, diverse nannofossil assemblages (Table 1).

The LOD of $H$. sellii is recognized at 123 mbsf. As stated previously, the LOD of $H$. sellii may be diachronous, because it appears to range between 1.37 and $1.19 \mathrm{Ma}$. In the Japan Sea, interpolation between the base of the Jaramillo ( $94.65 \mathrm{mbsf}$; $0.98 \mathrm{Ma}$ ) and the top of the Olduvai in Hole 798B (200.8 mbsf; $1.66 \mathrm{Ma}$ ) magnetic events yields an age for the LOD of $H$. sellii at this site of $1.16 \mathrm{Ma}$. This, of course, assumes constant sedimentation rates during this interval, which probably did not occur. The presence of $H$. sellii in Holes 798A and 798B is sporadic, occurring in only seven samples in the Pleistocene sequence. Yet, its last occurrence is unmistakable and its sporadic distribution useful in correlating between Holes 798A and 798B. Helicosphaera sellii is an order of magnitude more abundant (A) near the base of Hole 798A in Section 128-798A-15H-6, $67 \mathrm{~cm},(140.87$ mbsf) than anywhere else in that hole. It is also equally as abundant in Hole 798B in Section 128-798B-16H-1, $68 \mathrm{~cm}$, (143.28 mbsf). Nowhere else in this hole is $H$. sellii as abundant. Furthermore, the LOD of $C$. macintyrei $(10 \mu \mathrm{m})$ is coeval with this interval in both holes (Fig. 1).

The LOD of $C$. macintyrei $(10 \mu \mathrm{m})$ is recognized at $142.5 \mathrm{mbsf}$ in Samples 128-798A-15H-6, $57 \mathrm{~cm}$, and 128-798B-16H-1, $68 \mathrm{~cm}$. The extinction of $C$. macintyre $i$ is reportedly synchronous at $1.45 \mathrm{Ma}$ (Backman and Shackleton, 1983). However, interpolation between the base of the Jaramillo in Hole 798A and the top of the Olduvai in Hole 798B results in a last occurrence of $10 \mu \mathrm{m}$-sized Calcidiscus macintyrei at $1.33 \mathrm{Ma}$. Specimens of Calcidiscus in the Leg 128 cores do not exhibit the bimodal distribution that separates smaller $C$. leptoporus from the $10 \mu \mathrm{m}$ or greater sized $C$. macintyrei as was 
observed by Backman and Shackleton (1983) in the Atlantic, Pacific, and Indian Oceans. Throughout the Leg 128 cores, most Calcidiscus specimens range in size 5-8 $\mu \mathrm{m}$ with $36-40$ elements. The largest Calcidiscus specimens reach just over $10 \mu \mathrm{m}$ and it is questionable whether these belong in the species $C$. macintyrei.

\section{Calcareous Nannofossil Distribution (Table 1)}

Eighteen species of calcareous nannofossils are recognized in 469 smear slide samples of sediments taken at intervals of $0.75 \mathrm{~m}$ from cores recovered from Holes 798A and 798B. A tabulation of the relative abundance and preservation of these species is presented in Table 1. Remarkably apparent in the Quaternary sediments are the alternating intervals of barren sediment with those intervals that are nannofossil-rich on a scale of several meters to several tens of meters. Equally apparent is the marked decrease in nannofossil preservation, assemblage abundances, and diversity observed from $\sim 175(\sim 1.5 \mathrm{Ma})$ to 329 mbsf (the deepest recognizable nannofossil) at Site 798 (Table 1). From 329 mbsf to the base of Hole 798 at 517.9 mbsf, calcareous nannofossils are absent.

Thus, the sequence of sediments cored at Site 798 can be divided into three units on the basis of calcareous nannofossil diversity, preservation, and assemblage abundance. Nannofossil Unit A extends from the top of the core to $\sim 175 \mathrm{mbsf}$. This unit is characterized by nannofossil-rich layers several meters thick separated by barren or near barren intervals having a thickness $>3 \mathrm{~m}$. Eleven alternating layers can be recognized in this unit (Table 1). The nannofossil assemblages in these eleven layers are subdivided and described as follows:

\section{Nannofossil Unit Al (0.00-11.50 mbsf; 0.00-0.125 Ma)}

This nannofossil-rich layer contains the following nine species of calcareous nannofossils (abundances in parentheses): Calcidiscus leptoporus (F-C); Coccolithus pelagicus $(\mathrm{C}-\mathrm{A})$; Gephyrocapsa caribbeanica $(\mathrm{F}-\mathrm{A}) ;$ G. oceanica $(\mathrm{C}-\mathrm{V}) ;$ Helicosphaera carteri $(\mathrm{R}-\mathrm{F}) ; H$. columbiana (R); Pontosphaera sp. (F); small Reticulofenestra sp. $(\mathrm{F}-\mathrm{A})$; and Emiliania huxleyi $(\mathrm{F}-\mathrm{A})$. Preservation is generally poor. There are two $\sim 0.75-1.0-\mathrm{m}$-thick barren intervals within this unit. The first appearance of E. huxleyi is found at $9.32 \mathrm{mbsf}$ in Sample 128-798A-2H-1, $2 \mathrm{~cm}$.

\section{Nannofossil Unit A2 (11.5-25.00 mbsf; 0.125-0.29 Ma)}

This essentially barren interval has four $\sim 0.75-1.0$-m-thick nannofossil-rich horizons. Ten species of nannofossils and their abundances are recognized in these horizons: Braarudosphaera bigelowii $(\mathrm{F})$; C. leptoporus (C); C. pelagicus (A); Gephyrocapsa aperta (A); G. caribbeanica $(\mathrm{H}) ; G$. oceanica $(\mathrm{V}) ; H$. carteri $(\mathrm{C}) ; H$. wallichi $(\mathrm{F})$; and small Reticulofenestra sp. (A). Preservation ranges from poor to moderate.

Nannofossil Unit A3 (25.00-52.29 mbsf; 0.29-0.56 Ma)

This nannofossil-rich interval has three $\sim 0.75-1.0$-m-thick barren horizons. Eleven nannofossil species and their abundances are recognized in this interval: Braarudosphaera bigelowii $(\mathrm{F})$; C. leptoporus (C); C. pelagicus $(\mathrm{F}-\mathrm{V})$; G. aperta $(\mathrm{A}-\mathrm{H}) ;$ G. caribbeanica $(\mathrm{C}-\mathrm{A})$; G. oceanica $(\mathrm{A}-\mathrm{H}) ; H$. carteri $(\mathrm{C}-\mathrm{A}) ; H$. wallichi $(\mathrm{F}) ; P$. lacunosa (F-C); Pontosphaera sp. (F); and small Reticulofenestra sp. (A-V). Preservation ranges from moderate to poor. The LOD of $P$. lacunosa is at $39.75 \mathrm{mbsf}$ in Sample 128-798A-5H-3, $5 \mathrm{~cm}$.

\section{Nannofossil Unit A4 (52.29-60.22 mbsf; 0.56-0.62 Ma)}

This is an essentially barren interval with an $\sim 1$-m-thick interbedded nannofossil-rich horizon. Six species of nannofossils and their abundances are recognized in this interval: Calcidiscus leptoporus
(R); C. pelagicus (F-C); G. aperta (A); G. caribbeanica (C); $G$. oceanica $(\mathrm{F}-\mathrm{V})$; and Pontosphaera japonica $(\mathrm{F})$. Poorly preserved unidentified placoliths are few.

\section{Nannofossil Unit A5 (60.22-85.83; 0.62-0.85 Ma)}

Nannofossil Unit A5 is a nannofossil-rich layer with two 1-mthick interbedded barren horizons. Fourteen species of nannofossils and their abundances are recognized: Braarudosphaera bigelowii $(\mathrm{F}) ;$ C. leptoporus $(\mathrm{R}-\mathrm{A}) ;$ C . pelagicus $(\mathrm{C}-\mathrm{V})$; Dictyococcites productus (C-A); G. aperta (C-H); G. caribbeanica (C-V); G. oceanica $(\mathrm{C}-\mathrm{V}) ;$ H. carteri $(\mathrm{F}-\mathrm{C}) ;$ H. wallichi $(\mathrm{R}-\mathrm{F})$; Pontosphaera sp. (R-F); P. japonica $(\mathrm{F}) ;$ P. lacunosa $(\mathrm{F}-\mathrm{C})$; small Reticulofenestra sp. $(\mathrm{A}-\mathrm{V})$; and Reticulofenestra asanoi $(\mathrm{R}-\mathrm{A})$. Preservation is moderate where species diversity and abundances are high, and poor where they are low. The LOD of Reticulofenestra asanoi is found at $75 \mathrm{mbsf}$ in Sample 128-798A-9H-1, $6 \mathrm{~cm}$. The Brunhes/Matuyama boundary is found at 75.34 mbsf in Section 128-798A-9H-1.

Nannofossil Unit A6 (85.83-91.13 mbsf; 0.85-0.91 Ma)

This unit is barren of nannofossils. The top of the Jaramillo is at 90.55 mbsf in Section 128-798A-10H-6.

Nannofossil Unit A7 (91.13-94.83 mbsf; 0.91-0.98 Ma)

In this nannofossil-rich interval nine species of nannofossils and their abundances are recognized: Braarudosphaera bigelowii $(\mathrm{F}) ; C$. pelagicus (C-V); G. aperta (V); H. carteri (R-C); Pontosphaera sp. (F); P. japonica (R-F); P. lacunosa (C); small Reticulofenestra sp. (C); and Reticulofenestra asanoi $(\mathrm{F})$. Preservation is poor. Of particular note is the absence of $C$. leptoporus and $G$. oceanica.

\section{Nannofossil Unit A8 (94.83-97.15 mbsf; 0.98-1.0 Ma)}

This unit is barren of nannofossils.

\section{Nannofossil Unit A9 (97.15-105.23 mbsf; 1.0-1.05 Ma)}

In this nannofossil-rich interval ten species of nannofossils and their abundances are recognized: Calcidiscus leptoporus (R-A); $C$. pelagicus $(\mathrm{C}-\mathrm{V}) ;$ D. productus $(\mathrm{F}) ;$ G. aperta $(\mathrm{C}-\mathrm{H}) ;$ H. carteri $(\mathrm{F})$; Pontosphaera sp. (F-C); P. japonica (F); P. lacunosa (F-C); small Reticulofenestra sp. (F-A); and Reticulofenestra asanoi (F-C). Preservation is poor. G. oceanica is noticeably absent.

\section{Nannofossil Unit A10 (106.12-115.59 mbsf; 1.05-1.11 Ma)}

This unit is barren of nannofossils.

\section{Nannofossil Unit A11 (115.59-173.77 mbsf; 1.11-1.50 Ma)}

Unit A11 is a nannofossil-rich interval with eight $\sim 0.75$-m-thick barren horizons. Fourteen nannofossil species and their abundances are recognized in this unit: Braarudosphaera bigelowii (C); $C$. leptoporus ( $\mathrm{R}-\mathrm{A}) ; C$. macintyrei $(10 \mu \mathrm{m})(\mathrm{R}-\mathrm{C}) ; C$. pelagicus $(\mathrm{F}-\mathrm{V}) ;$ D. productus $(\mathrm{F}-\mathrm{C}) ;$ G. aperta $(\mathrm{C}-\mathrm{A}) ; G$. caribbeanica (F-V); G. oceanica $(\mathrm{R}-\mathrm{V}) ; H$. carteri $(\mathrm{R}-\mathrm{F}) ; H$. sellii $(\mathrm{C}-\mathrm{A})$; Pontosphaera sp. (F); P. japonica (R-C); P. lacunosa (F-C); small Reticulofenestra sp. (F-V); and Reticulofenestra asanoi (F-A). Preservation is poor. Due to extremely poor preservation in certain horizons, unidentified placoliths are few to abundant. The FOD of Reticulofenestra asanoi is found at 131.72 mbsf in Sample 128$798 \mathrm{~A}-14 \mathrm{H}-7,71 \mathrm{~cm}$. The LOD of $C$. macintyrei $(10 \mu \mathrm{m})$ is found at $140.87 \mathrm{mbsf}$ in Sample 128-798A-15H-6, $67 \mathrm{~cm}$ and at $143.28 \mathrm{mbsf}$ in Sample 128-798B-16H-1, $68 \mathrm{~cm}$. 
Nannofossil Unit B(175.27-329.56 mbsf; 1.50 Ma-middle Miocene)

Unit B is characterized by sporadic occurrences of very poorly preserved, low diversity, sometimes unidentifiable assemblages. Four species and their abundances may be recognized in these horizons. They are $C$. pelagicus $(\mathrm{F}-\mathrm{C}$, C. leptoporus $(\mathrm{F}), G$. caribbeanica $(\mathrm{F})$, and $H$. sellii $(\mathrm{F}-\mathrm{C})$. Unidentifiable nannofossils are the most abundant (F-C) component in these horizons. The top of the Olduvai is found in Section 128-798B-21X-7. No reliable calcareous nannofossil biostratigraphic or magnetostratigraphic age controls are available below the top of the Olduvai at Site 798 .

\section{Nannofossil Unit C (329.56-505.31 mbsf; Pliocene-late Miocene)}

Unit $\mathrm{C}$ is barren of nannofossils.

\section{Site 799}

Holes 799A and 799B were drilled in $\sim 2073 \mathrm{~m}$ of water on the southwestern end of the Kita-Yamato Trough. Fifty-four cores from Hole 799A and 63 cores from Hole 799B were analyzed for calcareous nannofossils. Although two samples/section (or a sample approximately every $0.75 \mathrm{~m}$ ) were generally described, only the best sample/section (approximately every $1.5 \mathrm{~m}$ ) is plotted (Table 2). A total of 660 samples was checked for calcareous nannofossils. Only 42 samples from Hole 799A (representative of 42 different sections) and 7 samples from Hole 799B contained nannofossils. With the exception of a few short intervals, nannofossil abundances and diversity are much lower and preservation much poorer at Site 799 than at Site 798. Unfortunately, there is little biostratigraphic control, index fossils are absent, and intervals of intense dissolution preclude biostratigraphic correlation between the two sites. The top four cores in Hole 799B recovered only $0.22 \mathrm{~m}$ of sediment. Due to coring problems, $\sim 20 \mathrm{~m}$ of section were lost between the base of Hole 799A at $468.7 \mathrm{mbsf}$ and the top of Section 128-799B-5H-1 at 489.6 mbsf.

The only biostratigraphic datum worth noting from either hole at Site 799 is the LOD of Pseudoemiliania lacunosa at $39.71 \mathrm{mbsf}$ in Sample 128-799B-6H-1, $22 \mathrm{~cm}$. This datum is considered reliable because it occurs in an anomalously well-preserved calcareous nannofossil assemblage, does not occur stratigraphically higher in other high-diversity assemblages, and persists consistently downsection in other high-diversity nannofossil assemblages.

\section{Calcareous Nannofossil Distribution (Table 2)}

All of the calcareous nannofossil species recognized at Site 798 are present in the Site 799 cores with the exception of Pontosphaera japonica, Reticulofenestra asanoi, and $H$. sellii.

\section{Hole 799A (0.0-81 mbsf; Top Section 128-799A-10H-3)}

The calcareous nannofossils recognized in Hole 799A from 0.0 to $~ 81$ mbsf consist of the same species found in the upper Pleistocene at Site 798 except that $E$. huxleyi is absent. Within the top $81 \mathrm{~m}$ at Site 799 , nannofossil-bearing intervals are separated by intervals up to $9.5 \mathrm{~m}$ thick that are barren of nannofossils. There are 25 nannofossil-bearing core sections and 27 barren core sections based on observations made on two samples/section taken at $\sim 0.75 \mathrm{~m}$ intervals. Preservation in the non-barren intervals ranges from extremely poor to good and nannofossil abundances range from rare to highly abundant. No one species occurs at every horizon; however, certain species do tend to dominate the assemblages in most horizons. Deposition within a fluctuating CCD during the time period represented by this section may account for the alternating barren and nannofossil-rich intervals.

The following species occur between 0.0 and $81 \mathrm{mbsf}$. (The numbers following the species indicate the percent of the 25 total core sections that contain that particular species): Braarudosphaera bigelowii
(F), $8 \%$; C. leptoporus (C), 20\%; C. pelagicus (F-A), 88\%; G. aperta $(\mathrm{F}-\mathrm{H}), 52 \%$; G. caribbeanica $(\mathrm{C}-\mathrm{H}), 48 \%$; G. oceanica $(\mathrm{F}-\mathrm{V}), 56 \%$; H. carteri $(\mathrm{F}), 8 \% ; H$. columbiana $(\mathrm{C}), 4 \% ; H$. wallichi $(\mathrm{F}), 4 \%$; Pontosphaera sp. (F-A), 36\%; P. lacunosa (F-C), 28\%; small reticulofenestrids (A-H), 64\%; and unidentified placoliths (F-V), 36\%.

Holes 799A and 799B (82.3-1084 mbsf; Sample 128-799A-10H-4 to Sample 128-799B-67R-CC)

Unlike the calcareous nannofossils found in the Pleistocene section at Site 798 and the top 81 m of section at Site 799, the distribution, abundance, and assemblage diversity of nannofossils below $81 \mathrm{mbsf}$ (lower Pleistocene) appears to be primarily controlled by in-situ dissolution and the production of authigenic carbonates. Many of the barren intervals between $80 \mathrm{mbsf}$ and the bottom of Hole 799B at $1084 \mathrm{mbsf}$ are rich in nannofossil size carbonate grains. It is interesting to note that nannofossils from Samples 128-799A-13H-5, $96 \mathrm{~cm}$ (113.7 mbsf) and -14H-5, $66 \mathrm{~cm}$ (122.7 mbsf) are almost monospecific assemblages of highly overgrown Coccolithus pelagicus. These samples also contain a high percentage $(60 \%)$ of carbonate debris ranging in size from 1 to $12 \mu \mathrm{m}$. Both $C$. pelagicus and the carbonate grains exhibit the same degree of high birefringence when viewed with crossed polarized light. Many of the $C$. pelagicus specimens are fragmented and it is apparent that many of the carbonate grains are fragments of $C$. pelagicus because some of these fragments, although highly dissolved and overgrown, retain some vestigial characteristics of $C$. pelagicus. And, in some cases, the fragments have not been disseminated, retaining the shape and size of the original nannofossil. In fact, within these two samples it is possible to see varying degrees of dissolution and overgrowth of $C$. pelagicus as specimens are converted to the end-member carbonate grains. Thus, it is reasonable to suspect that the carbonate grains that dominate the non-biogenous component of these samples came from in-situ dissolution of the nannofossils at these horizons and subsequent alteration and overgrowth. Coccolithus pelagicus, one of the most dissolution-resistant calcareous nannofossils, is all that remains of an assemblage of nannofossils that may have been as diverse as those found upsection at this site. Many of the downsection intervals are dominated by small, nannofossil-size, carbonate grains very similar to those found in these samples. The only difference is that with depth, dissolution increases, and these fragments, if they do represent former nannofossil deposits, do not contain any recognizable nannofossil structures. With the exception of Sample 128-799A-12H-6, $85 \mathrm{~cm}$ (good preservation, high diversity), dissolution-resistant $C$. pelagicus is the only identifiable species in most nannofossil-bearing samples.

Of particular note is an assemblage of nannofossils found in the core catcher of Core 128-799B-56X. Poorly preserved and highly overgrown Braarudosphaera bigelowii, C. pelagicus, Cyclicargolithus sp., and six-rayed discoasters reminiscent of Discoaster deflandrei and Discoaster variabilis are recognized. Also present are reworked Cretaceous Watznaueria barnesae. No age assignments are possible for this sample because some, if not all, of the Cenozoic nannofossils may have been reworked. This assemblage was not plotted in Table 2.

\section{PLEISTOCENE PALEOCEANOGRAPHY}

Alternating barren and nannofossil-rich sediments observed in cores from Site 798 record changing paleoceanographic and paleoclimatic conditions in the Japan Sea during the last $\sim 1.5$ m.y. In order to decipher the nannofossil paleoceanographic signal, it is first necessary to understand the present day oceanography. The following synopsis of modern Japan Sea oceanography is from Hidaka (1966) and Mogi (1979).

The Japan Sea is connected to the Pacific Ocean and adjacent seas by five narrow, shallow straits. The deepest $(130 \mathrm{~m})$ is the Tsushima Strait, which separates Korea from Honshu. During intense global 
glacial periods, when sea level may have been $85-130 \mathrm{~m}$ lower than present, it is possible that the Japan Sea may have been totally or near totally isolated from any connection with the warmer Pacific Ocean currents. Today, a branch of the northward-flowing warm-water Kuroshio Current enters the Japan Sea through the Tsushima Straits and is geostrophically forced east toward the western coast of Japan (Fig. 3). This affects the salinity and temperature of the eastern and southeastern Japan Sea, producing warmer and higher salinity water. Three cold, low-salinity currents enter the Japan Sea from the north, resulting in colder, less saline surface waters in the northern and western half of the sea. A distinct boundary, or oceanographic front (approximately along the $38^{\circ}-40^{\circ}$ parallel), exists where these two surface-water masses converge and mix (Fig. 3). The convergence zone between these two surface water masses can be identified in satellite images which measure the phytoplankton pigment concentration in the ocean. Phytoplankton pigment concentration within the convergence zone is $\sim 2-3$ times greater $\left(0.5-0.7 \mathrm{mg} / \mathrm{m}^{3}\right)$ compared to the pelagic environment $\left(0.25-0.35 \mathrm{mg} / \mathrm{m}^{3}\right)$ directly north and south of the convergence zone/oceanographic front. Regions with the highest phytoplankton pigment concentration $\left(0.7 \mathrm{mg} / \mathrm{m}^{3}\right)$ are plotted in Figure 3. This high productivity zone also coincides with the $4^{\circ}-8^{\circ} \mathrm{C}$ average February sea surface isotherms.

Sea ice is annually present in the Japan Sea for up to 200 days in the extreme northern part of the Tartar Strait, and for up to 120 days around Vladivostok and the Maritime Province. Severe winter cooling of the northern Japan Sea and the formation and spring melting of sea ice results in intense mixing and rapid convective overturn of the bottom waters. This, in turn, creates a shallow thermocline, highly oxygenated bottom and deep waters, and a shallow CCD.

Today, Site 798 is located in warm surface water south of the oceanographic front. However, in response to Pleistocene glacial episodes, it is reasonable to suspect that in the past $1.5 \mathrm{~m}$.y., the front may have migrated southward over the Oki Ridge as climate deteriorated, sea level dropped, the influence of the warm-water Tsushima Current diminished, and the formation of sea ice intensified.

Might the Pleistocene nannofossil record at Site 798 record the oscillation/migration of the oceanographic front over Site 798 as the Japan Sea responded to glacial/interglacial cycles? If this is the case, as the oceanographic front migrated southward over Site 798 in response to global glaciation, cooler surface water would probably replace warmer surface water. This, in turn, may have resulted in a reduced calcareous nannoplankton diversity dominated by cooler water forms such as $\mathrm{Coc}$ colithus pelagicus. A shallowing of the $\mathrm{CCD}$ in response to global glacial periods might also be expected. Conversely, when Site 798 was located south of the oceanographic front in warmer water, assemblage diversity may have been higher, dominated by warmer water forms such as Gephyrocapsa oceanica.

It is important to realize that although glacial/interglacial cycles may have been the primary influence on Japan Sea oceanography during the last $1.5 \mathrm{~m} . \mathrm{y}$., there is no reason to expect that the changing oceanographic conditions indicated by the nannofossil and percent carbonate record in the sediments be strictly synchronous with global ice volume changes recorded in the carbonate oxygen isotope record.

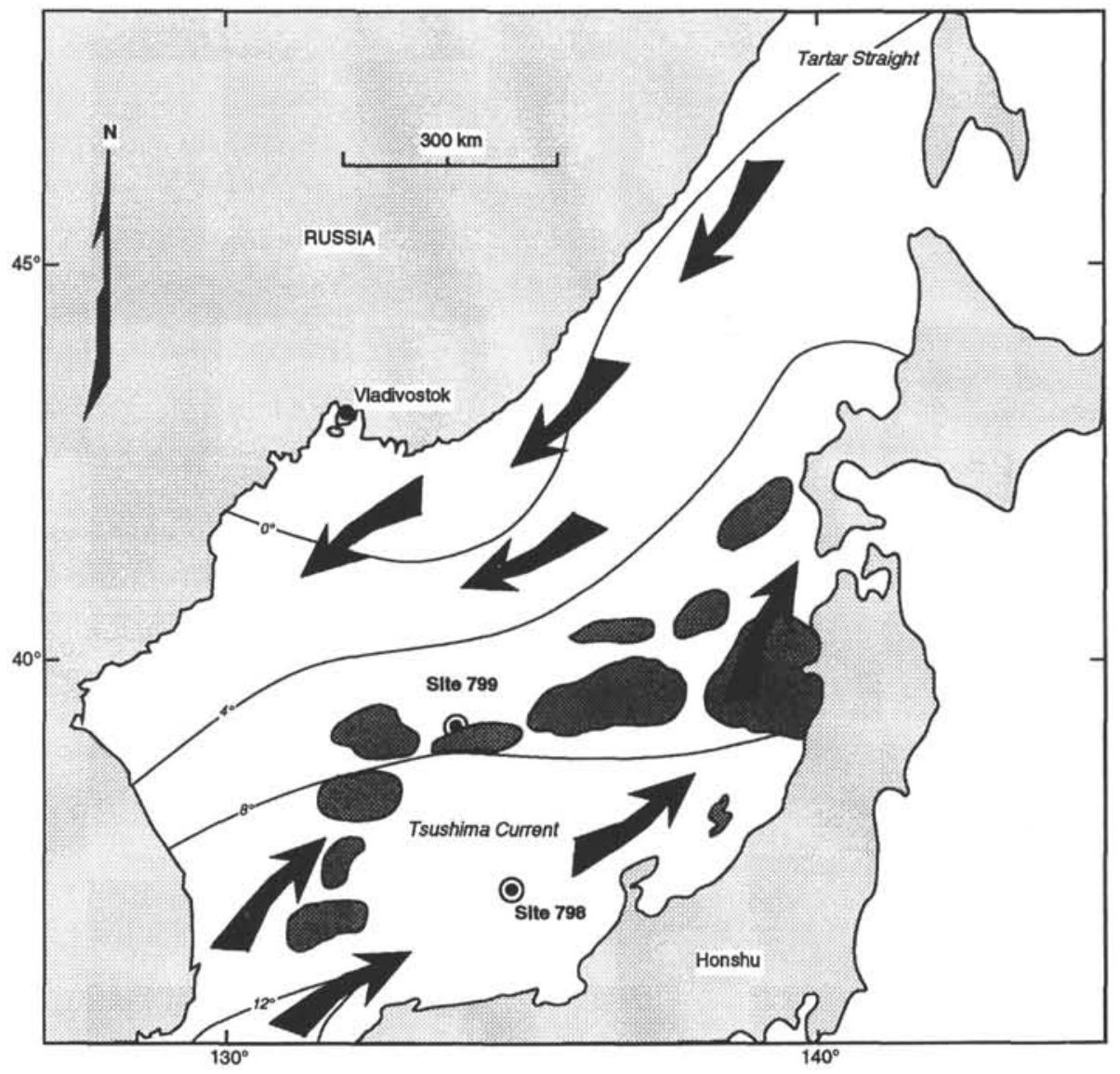

Figure 3. Location of the Japan Sea oceanographic frontal zone and associated region of high productivity (dotted) measured by phytoplankton pigment concentration $\left(0.6-0.7 \mathrm{mg} / \mathrm{m}^{3}\right)$ derived from satellite imagery. Cold water currents flowing southward converge and mix with the northward flowing Tsushima Current creating the oceanographic front. The region between the $4^{\circ}$ and $8^{\circ} \mathrm{C}$ average February isotherms approximates the oceanographic frontal zone. The location of Sites 798 and 799 is indicated by circled dots. 


\section{Possible Oceanographic Frontal Oscillation in the Japan Sea During the Last 1.5 m.y.}

Based on the interpretation of the nannofossil record from Site 798 (Table 1) and the scenario described in the last section of this report, a chronology is presented for the apparent migrations of the oceanographic front separating cooler surface water in the western and northern part of the Japan Sea from warmer surface water brought in by the Tsushima Current in the eastern and southern Japan Sea.

0-125,000 yr-The oceanographic front was probably north of Site 798 throughout most of this period as it is today. G. oceanica is 1-2 orders of magnitude more abundant than $C$. pelagicus, and assemblages are relatively diverse.

$125,000-288,000 \mathrm{yr}-$ The oceanographic front probably was south of the site throughout most of this period. The CCD was likely shallower than it is today because most of the sediments deposited during this period are barren of nannofossils. However, four short periods of time are recognized in this interval (see Table 1) when the CCD may have been deeper (short nannofossil-rich intervals) and/or the front oscillated over the site.

$288,000-560,000 \mathrm{yr}$-The nannofossil assemblages may represent a period of warmer surface water when the oceanographic front may have been north of the site. Assemblage diversity is high and G. oceanica is two orders of magnitude more abundant than $C$. pelagicus.

$\mathbf{5 6 0 , 0 0 0 - 6 2 0 , 0 0 0 ~ y r - B a r r e n ~ i n t e r v a l s ~ i n d i c a t e ~ t h a t ~ d u r i n g ~ m o s t ~ o f ~}$ this period the oceanographic front was located south of Site 798. One $15,000-20,000 \mathrm{yr}$ excursion of the front to the north of the site with a corresponding deepening of the CCD is recognized by an assemblage of nannofossils in which $G$. oceanica is generally two orders of magnitude more abundant than $C$. pelagicus.

$620,000-850,000 \mathrm{yr}$-The oceanographic front may have been north of the site. Gephyrocapsa oceanica is an order of magnitude more abundant than $C$. pelagicus, and the high diversity assemblage is characteristic of warmer water.

$850,000-910,000 \mathrm{yr}$-The oceanographic front was probably south of Site 798. This interval is essentially barren, possibly indicating a CCD shallower than the top of the Oki Ridge.

910,000-980,000 yr-The front may have been directly over the site during this interval. Nannofossil diversity is high, but warmer water forms such as $G$. oceanica and $C$. leptoporus are noticeably absent. Because $C$. leptoporus may not be able to tolerate temperatures lower than $5^{\circ} \mathrm{C}$ (Okada and McIntyre, 1979), its absence might indicate surface-water temperatures lower than $5^{\circ} \mathrm{C}$ during this time. Coccolithus pelagicus dominates the assemblage. Surface water temperatures probably were not warm enough to support $G$. oceanica, but the climate had ameliorated to the point where the CCD was depressed sufficiently to allow carbonate accumulation.

$980,000 \mathrm{yr}-1.00 \mathrm{Ma}$-The front probably was located south of Site 798. Possibly, a shallow CCD during this time period precluded the accumulation of calcareous sediments.

1.00-1.05 Ma-The front may have been north of the site during this period. Although assemblages are relatively diverse, Gephyrocapsa oceanica is absent, indicating that the surface waters may not have been warm enough to support this species.

1.05-1.11 Ma-Barren intervals may indicate that the site was north of the front and surface waters were too cold for calcareous nannoplankton, or that the $\mathrm{CCD}$ was shallow enough to preclude nannofossil accumulation.

1.11-1.50 Ma-The front probably was north of Site 798 throughout much of this period, although there is some indication (barren intervals; absence of $G$. oceanica in some assemblages) that cooler surface water periodically covered the site and that the CCD may have been much shallower.

1.50 Ma to base of hole-The in-situ dissolution of the nannofossil assemblages older than $1.5 \mathrm{Ma}$ hinders the reconstruction of surface water paleoceanographic boundaries, and no such attempts are made here.

Correlation of the Site 798 Pleistocene oceanographic front oscillation/migration model to the SPECMAP oxygen isotope curve of Imbrie et al. (1984) does not reveal any obvious contradictions to the global oxygen isotope ice-volume record, nor do such comparisons conclusively support this model. On the other hand, the nannofossil biochronostratigraphic resolution in this study is hampered by widely spaced sampling intervals in the Site 798 cores. Additional closely spaced sampling is needed to achieve better chronostratigraphic resolution to adequately correlate the nannofossil record to the SPECMAP oxygen isotope curve and curves derived from the Japan Sea. That is the object of current research.

\section{Comparison to DSDP and Other ODP Sites}

Ocean Drilling Program Leg 127 Sites 795 and 796 and Deep Sea Drilling Project Leg 31 Sites 300,301, and 302 are north of the present day oceanographic front. The Pleistocene nannofossil assemblages recorded from these sites (Rahman, this volume; Ellis, 1975) appear to indicate that the Pleistocene surface waters were generally too cold to support diverse nannofossil assemblages. In fact, much of the Pleistocene nannofossil record appears to be missing at these sites. This probably is due to deposition below the CCD. All of these sites were drilled in water between 2223 and $3350 \mathrm{~m}$. Ocean Drilling Program Sites 794, 797, and 799 were also drilled in deep water at 2825,2945 , and $2073 \mathrm{~m}$, respectively. Their locations place them near or within the present day surface water oceanographic front. The Pleistocene nannofossil assemblages and distribution at these sites appear to be controlled more by the depth of the CCD than by any direct climatic effects such as sea-surface temperature or salinity variations. Unfortunately, no other location was drilled at a sufficiently shallow depth (above the modern CCD) to enable the nannofossil record at those sites to be correlated with the nannofossil events at Site 798.

\section{ACKNOWLEDGMENTS}

I would like to thank the Leg 128 co-chiefs, Jim Ingle and Kiyoshi Suyehiro, the scientific party and ODP technical staff, and the captain and crew of the JOIDES Resolution. This paper benefited from the reviews of J. Barron, L. Bybell, W. Abbott, E. Joyce, M. Filewicz, and S. Wise. I would also like to thank Sherwood Wise and Lloyd Burckle for the hours of invaluable discussion concerning this paper and other projects. Leslie Moore assisted with manuscript preparation.The ODP staff at Texas A\&M University deserve special thanks for their assistance. Lastly, I would like to thank the ODP for the opportunity to participate on Leg 128. Funding for this project was provided by a grant from USSAC.

\section{REFERENCES}

Backman, J., and Shackleton, N. J., 1983. Quantitative biochronology of Pliocene and early Pleistocene calcareous nannofossils from the Atlantic, Indian, and Pacific oceans. Mar. Micropaleontol., 8:141-170.

Berggren, W. A., Kent, D. V., and van Couvering, J. A., 1985. The Neogene: Part 2. Neogene geochronology and chronostratigraphy. In Snelling, N. J. (Ed.), The Chronology of the Geologic Record. Mem.-Geol. Soc. Am., 10:211-260.

Bukry, D., 1973a. Coccolith and silicoflagellate stratigraphy, Northwestern Pacific Ocean, Deep Sea Drilling Project Leg 32. In Larson, R. L., Moberly, R., et al., Init. Repts. DSDP, 32: Washington (U.S. Govt. Printing Office), 677-701.

- 1973b. Low latitude coccolith biostratigraphic zonation. In Edgar, N. T., Saunders, J. B., et al., Init. Repts. DSDP, 15: Washington (U.S. Govt. Printing Office), 685-703. 
Ellis, C. H., 1975. Calcareous nannofossil biostratigraphy-Leg 31, DSDP. In Karig, D. E., Ingle, J. C., Jr., et al., Init. Repts. DSDP, 31: Washington (U.S. Govt. Printing Office), 655-676.

Gartner, S., 1977. Calcareous nannofossil biostratigraphy and revised zonation of the Pleistocene. Mar. Micropaleontol., 2:1-25.

Haq, B. U., Berggren, W. A., and Van Couvering, J. A., 1977. Corrected age of the Pliocene/Pleistocene boundary. Nature, 269:483-488.

Hay, W. W., 1970. Calcareous nannofossils from cores recovered on Leg 4. In Bader, R. G., Gerard, R. D., et al., Init. Repts. DSDP, 4: Washington (U.S. Govt. Printing Office), 455-501.

Hay, W. W., Mohler, H., Roth, P. H., Schmidt, R. R., and Boudreaux, J. E., 1967. Calcareous nannoplankton zonation of the Cenozoic of the Gulf Coast and Caribbean-Antillean area, and transoceanic correlation. Trans. Gulf Coast Assoc. Geol. Soc., 17:428-480.

Hidaka, K., 1966. Japan Sea. In Fairbridge, R. W. (Ed.), The Encyclopedia of Oceanography. Encyclopedia of Earth Sci. Ser. (Vol. 1): New York (Reinhold), 417-424.

lijima, A., and Tada, R., 1990. Evolution of Tertiary sedimentary basins of Japan in reference to opening of the Japan Sea. J. Fac. Sci., Univ. Tokyo, 22:121-171.

Ingle, J. C., Jr., 1975. Summary of Late Paleogene-Neogene stratigraphy, paleobathymetry, and correlations, Philippine Sea and Sea of Japan region. In Karig, D. E., Ingle, J. C., Jr., et al., Init. Repts. DSDP, 31: Washington (U.S. Govt. Printing Office), 837-855.

Ingle, J. C., Jr., Suyehiro, K., von Breymann, M. T., et al., 1990. Proc. ODP, Init. Repts., 128: College Station, TX (Ocean Drilling Program).

Kamptner, E., 1943. Zur Revision der Coccolithineen-Spezies Pontosphaera huxleyi Lohm. Akad. Wiss. Wien, Math.-Naturwiss. KI., Anz., 80:43-49.

, 1963. Coccolithineen-Skelettreste aus Tiefseeablagerungen des Pazifischen Ozeans. Ann. Naturh. Mus. Wien, 66:139-204.

Matsuoka, H., and Okada, H., 1989. Quantitative analysis of Quaternary nannoplankton in the subtropical northwestern Pacific Ocean. Mar. Micropaleontol., 14:97-118.

Mogi, A., 1979. An Atlas of the Sea Floor Around Japan: Tokyo (Univ. of Tokyo Press), 74-88.

Okada, H., and McIntyre, A., 1979. Seasonal distribution of modern coccolithophorida in the Western North Atlantic Ocean. Mar. Biol., 54:319-328.

Perch-Nielsen, K., 1985. Cenozoic calcareous nannofossils. In Bolli, H. M., Saunders, J. B., and Perch-Nielsen, K. (Eds.), Plankton Stratigraphy: Cambridge (Cambridge Univ. Press), 427-554.

Pujos, A., 1985a. Nannofossils from Quaternary deposits in the high-productivity area of the central equatorial Pacific, Deep Sea Drilling Project Leg 85. In Mayer, L., Theyer, F., Thomas, E., et al., Init. Repts, DSDP, 85: Washington (U.S. Govt. Printing Office), 553-579.

1985b. Quaternary nannofossils from Goban Spur, eastern North Atlantic Ocean, Deep Sea Drilling Project Holes 548 and 549A. In de Graciansky, P. C., Poag, C. W., et al., Init. Repts. DSDP, 80: Washington (U.S. Govt. Printing Office), 767-792.
Pujos-Lamy, A., 1977. Emiliania et Gephyrocapsa (Nannoplancton calcaire): biometrie et interet biostratigraphique dans le Pleistocene superieur marin des Acores. Rev. Esp. Micropaleontol., 9:69-84.

Rahman, A., and Roth, P. H., 1989. Late Neogene calcareous nannofossil biostratigraphy of the Gulf of Aden region based on calcareous nannofossils. Mar. Micropaleontol., 15:1-27.

Samtleben, C., 1980. Die Evolution der Coccolithophoriden-Gattung Gephyrocapsa nach Befunden im Atlantik. Palaontol. Z., 54:91-127.

Takayama, T., and Sato, T., 1986. Coccolith biostratigraphy of the North Atlantic Ocean, Deep Sea Drilling Project Leg 94. In Ruddiman, W. F., Kidd, R. B., Thomas, E., et al., Init. Repts. DSDP, 94 (Pt. 2): Washington (U.S. Govt. Printing Office), 651-702.

Tamaki, K., 1988. Geological structure of the Japan Sea and its tectonic implications. Chishitsu Chosasho Geppo, 39:269-365.

Thierstein, H. R., Geitzenauer, K. R., Molfino, B., and Shackleton, N. J., 1977. Global synchroneity of late Quaternary coccolith datum levels: validation by oxygen isotopes. Geology, 5:400-404.

Date of initial receipt: 7 May 1991

Date of acceptance: 26 February 1992

Ms 127/128B-122

\section{APPENDIX}

Species List in Alphabetical Order of Generic Epithets

Braarudosphaera bigelowii (Gran and Braarud, 1935) Deflandre (1947) Calcidiscus leptoporus (Murray and Blackman, 1898) Loeblich and Tappan (1978)

Calcidiscus macintyrei (Bukry and Bramlette, 1969) Loeblich and Tappan (1978)

Coccolithus pelagicus (Wallich, 1877) Schiller (1930)

Dictyococcites productus (Kamptner, 1963) Backman (1980)

Discoaster deflandrei Bramlette and Riedel (1954)

Discoaster variabilis Martini and Bramlette (1963)

Emiliania huxleyi (Lohmann, 1902) Hay and Mohler in Hay et al. (1967) Gephyrocapsa aperta Kamptner (1963)

Gephyrocapsa caribbeanica Boudreaux and Hay (1969)

Gephyrocapsa oceanica Kamptner (1943)

Helicosphaera carteri (Wallich, 1877) Okada and McIntyre, 1977

Helicosphaera columbiana Gartner (1977)

Helicosphaera sellii Bukry and Bramlette (1969) Jafar and Martini, 1975

Helicosphaera wallichi (Lohmann, 1902) Boudreaux and Hay (1969)

Pontosphaera sp. (Lohmann) 1902

Pontosphaera japonica (Takayama, 1967)

Reticulofenestra sp. Hay, Mohler, and Wade (1966)

Reticulofenestra asanoi Sato and Takayama, 1990

Watznaueria barnesae (Black in Black and Bames, 1959) Perch-Nielsen (1968) 